\title{
Getting to the Point: How Many Quills Does A North American Porcupine (Erethizon Dorsatum) Have?
}

\author{
John G Shokeir* \\ University of Calgary, Canada
}

Submission: October 27, 2017; Published: November 29, 2017

*Corresponding author: John G Shokeir, University of Calgary, Canada, 30 Aspen Heights Way Innisfail, AB T4G 1Y5, Tel: (587) 876-5796; (403) 865-0092; Email: jgshokei@ucalgary.ca

\section{Abstract}

Hall [1] claimed that the North American porcupine (Erethizon dorsatum) possesses more than 30,000 quills. In this study, the author counted 44,006 quills from a captive twenty-two year-old porcupine. The potentially large variation in the number of quills in $E$. dorsatum could be the result of body mass variation, sex, and diet composition.

Keywords: Porcupine; Quills; Erethizon dorsatum

\section{Introduction}

The dorsal integumentary surface of the North American porcupine (Erethizon dorsatum) is covered with a dense layer of quills, a modified hair structure used for defence. Quills have a tapering point covered with microscopic barbs, allowing for simple penetration but difficult removal from tissue [2]. Despite the work done on the mechanical properties of porcupine quills [2,3] and literature on quill-related injuries [4], it remains unclear how many quills a typical porcupine possesses. Hall [1] claims the number exceeds 30,000 , but this figure may not reflect individual variation present in E. dorsatum. In this study, the author counted the total number of quills from an E. dorsatum individual, demonstrating that there could be significant individual variation in the number of quills in E. dorsatum.

\section{Materials and Methods}

The quills of a captive twenty-one-year-old North American porcupine were collected and counted in this study. The specimen's body mass was typical for a full-grown female porcupine (body mass=8.89041Kg); [5]. The porcupine had recently deceased due to multiple organ failure related to advanced age, but had not exhibited any signs of hair-loss or hair growth problems. To collect the quills for this study, the dorsal surface was denuded and the quills sorted from the surrounding hair. To ensure that hair was not included in the results, quills were counted by the number of sharp, pointed ends. Quills were weighed in sets of five hundred.

\section{Results}

In total, there were 44,006 porcupine quills, which is $46.7 \%$ greater than the original claim of 30,000 quills made by Hall [1]. The total mass of the quills was $490.98 \mathrm{~g}$ with a mean quill mass of $11.16 \pm 0.04 \mathrm{mg}$. Quills represented $5.52 \%$ of the body mass.

\section{Discussion}

When compared to the findings of Hall [1], this study demonstrates that the number of quills in E. dorsatum varies between individuals by a large degree. However, the cause of this variation remains unclear. If larger individuals have more quills than smaller individuals, then male porcupines, which tend to be several kilograms larger than females, would have more quills than female porcupines [5]. Given that quills are mainly composed of keratin proteins [2], the general health and dietary quality would also likely influence quill number. Swietzer \& Berger [5] suggest that female porcupines might assess male fitness based on quill number, so there is a possibility that male porcupines have a greater number of quills than females independent of body size. Further study is needed to determine the effect of size, health condition, and sex on quill number.

\section{Acknowledgements}

The author would like to thank Serena Bos for her assistance in providing me the specimen and for her consultation during the data collection of this project. 


\section{References}

1. Hall ER (1946) Mammals of Nevada. Berkeley (CA): Univ California Press p.710.

2. Cho WY, Ankrum JA, Guo D, Chester SA, Yang SY, et al. (2012) Micro structured barbs on the North American porcupine quill enable easy tissue penetration and difficult removal. PNAS 109(52): 21289-21294.

3. Vincent JFV and Owers P (1986) Mechanical design of hedgehog spines and porcupine quills. J Zool 210(1): 55-75.
4. Johnson MD, Magnusson KD, Shmon CL, and Waldner C (2006) Porcupine quill injuries in dogs: A retrospective of 296 cases (1998-2002). Can Vet J 47(7): 677-682.

5. Sweitzer RA, Berger J (1997) Sexual dimorphism and evidence for intrasexual selection from quill impalements, injuries, and mate guarding in porcupines (Erethilon dorsatum). Can J Zool 75(6): 847-854.

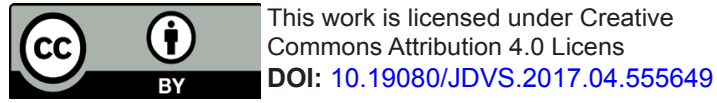

